\title{
Identity and fear - burials in the Upper Palaeolithic
}

\author{
Simona Petru \\ Deparment of Archaeology, Faculty of Arts, University of Ljubljana, Ljubljana, SI \\ Simona.Petru@ff.uni-lj.si
}

\begin{abstract}
Ritual burials probably appeared when human beings became aware of their existence not only at a given moment, but also in the future. Death then became something to be feared, since it annihilated the identity of the deceased. Consequently, a belief appeared that rituals at the time of death and proper handling of the corpse could preserve the identity of the dead, so that they only enter a different 'world', an afterlife, where life and personality continue in some way. Since finds of deformed and damaged skeletons in Upper Palaeolithic graves are relatively frequent, it may be possible to conclude that people at that time were particularly cautious with the bodies of those who, for a variety of reasons, had deviated from normal in their lifetime.
\end{abstract}

KEY WORDS - Upper Palaeolithic; burial practices; identity; relics

\section{Identitete in strah - pokopi v mlajšem paleolitiku}

\begin{abstract}
IZVLEČEK - Ritualni pokopi so se verjetno pojavili, ko se je človek zavedel, da ne obstaja samo v danem trenutku, temveč tudi v prihodnosti. Smrt je takrat postala nekaj, česar se je potrebno bati, saj je izničila identiteto umrlega. Zato se je pojavilo verovanje, da zaradi obredov v času smrti in primernega ravnanjem s truplom, smrt človeka ne izniči, temveč oseba le preide v drugačen 'svet', $v$ onostranstvo, kjer se življenje in osebnost na nekakšen način nadaljujeta. Ker so najdbe deformiranih in poškodovanih skeletov $v$ mlajšepaleolitskih grobovih relativno pogoste, bi morda lahko sklepali, da so posebej previdno ravnali s trupli oseb, ki so $v$ času življenja iz različnih razlogov odstopale od normale.
\end{abstract}

KLJUČNE BESEDE - mlajši paleolitik; pokopne prakse; identiteta; relikvije

\section{Introduction}

Upper Palaeolithic burials are rare events (Riel-Salvatore, Gravel-Miguel 2013.304), which could indicate that they were not the main practice of disposing of corpses. It seems that it was primarily those individuals who had visible physical deformities who were buried (Formicola 2007; Trinkaus, Buzhilova $2018.7)$ or were treated in some other way special, while corpses of 'normal' people were probably treated differently. There are many strategies and manners of treating the dead; they originate from different ideological, religious, social, and other factors.
If we generalise, we could say that deceased individuals who were 'normal' and lived 'normally' (therefore in accordance with the norms of a group) were treated differently from those who 'stood out'.

A good ethnological illustration is the contemporary East African Samburu tribe, who treat their deceased in different ways (Straight 2013.119-124). Some people, e.g., murderers, 'smell' bad, so their personality has to be annihilated, and even in death, completely eliminated from human society. On the other 
hand, with those who 'smell' good, these are primarily the elders of the tribe, some aspects of their personality can be preserved. Death is more dangerous for the living if a person dies in a particular period of life, in particular circumstances or in a particular place. Considering the level of danger that the death of an individual gives rise to, they decide in which manner the corpse, to which death clings like an infectious disease ready to spread, needs to be separated from the living. The majority of people, with the exception of old people and infants, are laid out under the trees. To prevent death from spreading to the living, the corpses have to be eaten, or at least thoroughly gnawed by hyenas. If these predators ignore the body, a goat is slaughtered nearby to attract them. Deceased children who were no longer breast-fed by their mother are also laid out under trees, away from the settlement. Since the death of a child is always bad, their jewellery and clothes are buried, not with them, but in a different place. In this way, the child is completely annihilated. Since he did not grow up and have children of his own, he leaves nothing to the living, and it is as if he never existed. The older a person is, the closer to the settlement they are buried, because the power of death clinging to a person lessens with age and becomes increasingly less 'contagious'. Old people are frequently buried inside the settlement or even in the house where their descendants live, because they influence the living beneficially. Children inherit jewellery and other possessions from their parents and grandparents, since their belongings do not pose a threat, and they can be remembered safely through these objects. Unmarried men and unmarried warriors together with their partners are considered dangerous people. The danger they present is so great that they even have to die far away from the settlement, and that is where their corpses remain. Their corpses are not stripped of clothing, and their jewellery is not taken, as is the habit with 'non-dangerous' deceased. Almost every aspect of the burial practices of the Samburu tribe is directed towards successfully 'cutting off' the dead from the living.

\section{Burial practices in the Upper Palaeolithic}

Similarities with such burial practices are revealed in certain burials in the Upper Palaeolithic. In the well-known triple burial from the site of Dolní Věstonice, the middle skeleton was highly deformed (Klima 1988.834; Formicola et al. 2001). Three young men (Mittnik et al. 2016) were buried in the grave in an unusual position. Their skulls were impregnated with red ochre, while the earth around the skulls was also red. The middle skeleton also had ochre sprinkled over its pelvis. In addition to the red pigment, the grave included pendants of pierced teeth and beads made of mammoth ivory (Klima 1988. 834-835). All three persons, who might have belonged to the same family (Alt et al. 1997), were probably buried simultaneously (Klima 1988.835). The middle person was laid in the grave first, followed by the persons to the left and right. Pieces of charred wood were found on the skeletons and around the grave, which led to the conclusion that the grave was covered with branches that were burned during the ritual burial. Since the skeletons were not burned, the fire had to be put out quickly (Klima 1988.835). During his lifetime, the middle person in the grave was probably marked as different due to his deformities and could have even enjoyed a special status in society (Mittnik et al. 2016.5). Both of the side skeletons displayed injuries (Pettitt 2011. 192), so it is possible that both young men were sacrificed upon death because they were related (Alt et al. 1997; Mittnik et al. 2016.5) or in some other way connected to the middle person. Other members of the group could have been afraid that they both were 'infected' by the death of the deformed individual and, therefore, they had to join him in the grave. It is possible that by lighting a fire above the bodies, the area was ritually cleansed in order to prevent death from spreading among the living.

The child's grave in the Portuguese rock-shelter of Lagar Velho was also cleansed with fire before the corpse was placed inside (Pettitt 2011.169). The skeleton is another example of deviation from the norm, since some believe that the child was a close descendant of interbreeding between modern humans and Neanderthals (Duarte et al. 1999), while others suggest that he was a very robust representative of modern humans (Tattersall, Schwartz 1999). The child's appearance was probably very unusual and this could be the reason he was buried. The exceptional nature of the event is indicated by the fact that no other $\mathrm{Pa}$ laeolithic burials are known from the territory of Portugal and, hence, burial was probably not the regular practice of corpse disposal.

Another triple burial from the Upper Palaeolithic is known, from the cave of Barma Grande. The grave included the skeletons of an adult man and two adolescents, probably female (Fig. 1).

The skeletons were sprinkled with ochre, and ornamented with jewellery made of pierced shells, red deer teeth, fish vertebrae, and mammoth ivory. The 
grave also included stone tools (Giacobini 2007). The similarity with the burial at Dolní Věstonice is in the number of people interred, the fact that in Barma Grande all three individuals were also buried simultaneously, and that the person in the middle was placed in the grave first (Pettitt 2011.182). Even though the male skeleton reveals a certain pathology (Formicola, Holt 2015.79), it is possible that in this case the burial was dictated by inappropriate social behaviour which, similarly to a physical deformation, 'stigmatised' individuals as socially dangerous. Nevertheless, the burial practices in each case could have been quite different, and the similarity between these two burials merely coincidental.

Pathological deformations are also known on skeletons from other Upper Palaeolithic burials. This leads us to believe that congenital deformation or later prolonged illness was one of the reasons such individuals were buried (Formicola et al. 2001) and thus placed under the ground, to make others safe from them. It is possible that deformed people had a special status during their lifetime, which could be concluded from the find of the skeletons of two adolescents in the extremely rich grave at the Russian site of Sunghir. A boy of 12 to 13 years of age and a girl between 9 and 10 years old were buried in a shallow grave. They were positioned in such a way that their skulls were touching. Both skeletons were highly decorated and surrounded with numerous grave goods. They were buried simultaneously. The girl's skeleton was deformed from illness; the signs of illness were most prominent upon her birth and subsided with age, enabling the girl to live an active life (Formicola, Buzhilova 2004; Trinkaus et al. 2014.18). Despite being deformed, the girl survived through childhood, but was treated differently from other members of the group upon her death, since she was buried. This could indicate that she was privileged in the society; on the other hand, it could also indicate the desire to remove her from the world of the living as successfully as possible. The adolescent male skeleton also had deformities (Trinkaus, Buzhilova 2018.11-12) and might even have suffered perimortem trauma (Trinkaus et al. 2014.282-283). They were buried with all their belongings, despite the effort put into the production of the artefacts, because their property became dangerous to the living and, rather than being preserved, was buried and eliminated from the life of the group.

Separation from the living is also evident in the burial at the Czech site of Brno, where a partial skeleton of a man who suffered from periostitis was dis-

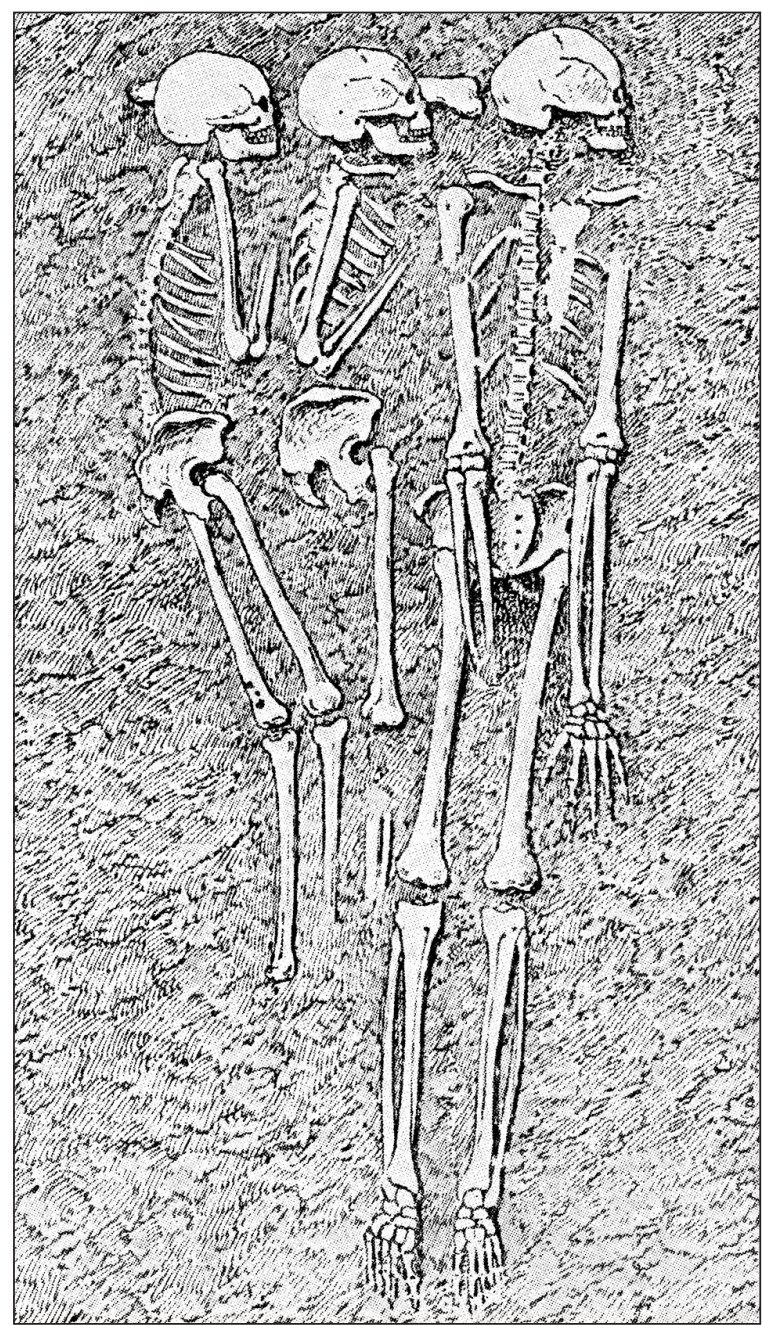

Fig. 1. Triple burial from the Barma Grande cave in Italy (Verneau 1900.Fig. 5).

covered. The inflammation was chronic and the man probably endured pain for several years. The skeleton was sprinkled with red ochre and possibly covered with mammoth scapula. Numerous grave goods were also found in the grave. It is interesting that the grave was located far away from any Palaeolithic settlement. The grave goods and the isolated position of the grave indicate that this is the burial of a special individual, possibly a shaman (Oliva 1999). He was probably considered a powerful and dangerous person, so he was buried far away from the settlement. Some groups of people who still practice shamanism today also bury or expose those shamans they fear far outside the settlement, and avoid that place thereafter. Occasionally, the hide of their drum is pierced, since the drum is the means that enables shamans to travel. With the act of destroying the drum, the shaman is prevented from returning to the community (Vitebsky 2001.95). Some also believe that a shaman is 'infectious' during his lifetime, since he unintentionally sucks the life from the 
people close to him, who are therefore sickly and die young (Vitebsky 2001.22).

Another example of the distinctive difference of a deceased person was found in the Italian rock shelter of the Riparo del Romito. An adult woman and an adolescent dwarf were buried in a shallow grave; it is not completely clear whether the burial was simultaneous. Three auroch bulls were engraved on a rock near the grave, while the grave included two fragments of this animal's horn. The adolescent dwarf was perhaps stigmatised as different since his birth. There is little doubt that he stood out by his appearance, since this is the only known example of dwarfism in the Palaeolithic. He could have been feared or, on the other hand, he might have had high status in the society because of his deformity (Frayer et al. 1988.549-550, with references; Giacobini 2007.14; Pettitt 2011.244-245).

In addition to illnesses, severe injuries could also have made members of a community contagious and dangerous, since bad luck and injury could spread to others. If people died of injuries outside the settlement, they were probably left at the place of death. If they died later on, surrounded by members of the community, they might be buried together with all their belongings, due to danger spreading from them and their property. This could be suggested for the case of a burial in the Arene Candide cave in Italy. Owing to the rich grave goods, this burial was named 'Il Principe'. A young man was buried in the grave. A part of a mandibula was missing, but the void had been filled with a great amount of ochre, which was in direct contact with the broken bone, as if someone had tried to hide or heal the injury that caused the death of the young man - a hunter who was at the peak of his strength. The skeleton was placed on a bed of ochre and had hundreds of perforated shells and teeth around the head, which were originally probably fixed to some sort of cap. Mammoth ivory pendants and four perforated batons were found beside the skeleton, while the right hand held a flint blade (Mussi 2001.257; Pettitt 2011.182). The man was probably buried with all his belongings, which had in this way disappeared from the world of the living together with him. Prior to the burial, the wound on the jaw could have been symbolically healed with ochre, so that the injury would not present a reason for him to 'return' among the living and harm them. The adult man from the rich grave in Sunghir also died violently (Trinkaus et al. 2014. 274; Trinkaus, Buzhilova 2018.9) and might have been buried for similar reasons as 'Il Principe'.
The combination of disease and injury is evident on one of the children's skeletons from the Italian site of Grotta dei Fanciulli. The grave of two children, who were lying in a shallow pit one next to the other, was found there. One of the children had a flint point stuck in a vertebra, which probably caused his death. The skeletons of both children show traces of periostitis, and one also bore rachitic lesions. The grave did not contain red ochre, but several hundred pierced shells decorated the area of the children's waist and pelvis. They could have originated from a garment which covered this part of their bodies (Henry-Gambier 2001.105-111; Giacobini 2007.5-6; Pettitt 2011.243-244). This indicates that the children might have been buried in their clothes to erase all traces of their existence among the living.

The situation with the Early Upper Palaeolithic burial at Kostenki 14 (Markina gora) is somewhat different. The skeleton of an adult man was found within the settlement, in a grave that was marked by red pigment. The body was buried in an extremely retracted position, the knees being pulled up to the chest. It is possible that he was buried tied up. The clenched fists of both hands, one of which was stuck in the mouth, indicate that the man suffered severe pain prior to his death (Sinitsyn 2004.238; Pettitt 2011.201). It could be that the man was violently executed due to his inappropriate deeds, and was then buried within the settlement as an example to others. This could also indicate that burial was a punishment, and was reserved for those who, for any reason, including, a moral one, deviated from the norm.

In the Upper Palaeolithic, people started recognising death as the annihilation of identity. This became possible only with the development of the episodic memory, which enabled humans to know that they would or would not exist in the future (Petru 2017. 403-404). With a realisation that someday the annihilation of the identity would happen, there arose the need for a belief in the afterlife in which the identity would be preserved at least to some extent. In a community, the identity of the deceased was preserved by the memory of the living, which was stimulated by the presence of his relics.

In the Vilhonneur cave in France, the partial skeleton of a young adult male was discovered; a hand stencil was outlined on the cave wall in the same chamber (Henry-Gambier et al. 2007). The presence of the hand stencil could reflect the awakening of self- 
recognition, since the handprint (Fig. 2) is probably one of the first documented signs of the recognition of personal identity and acceptance of the body as an integral part of this identity. Impressions or outlines of hands on the wall, just like burials or manipulation of human relics, express a desire for lasting the preservation of identity, which is not annihilated by death. Everyone has a different handprint, which is therefore linked to a particular individual, who wants to record his existence permanently and express his uniqueness within a group. Since identity is best expressed through the body, body parts assumed the identity of the deceased and became lasting objects kept through several generations. Thus, the deceased remained with their descendants not only in memory, but also physically.

The highest frequency of manipulation of the human body remains appears in the Magdalenian (Pettitt 2011.217). Modified skulls, which were probably used as skull-cups, are known from this period from Gough's Cave, where numerous fragmented human remains that belong to at least five to seven persons were found in layers dated to $14700 \mathrm{BP}$. The bones indicate that the flesh was removed from them and that they were cracked to extract the bone marrow. Traces of human teeth are also present on them. Special attention was focused on skulls, since they were not only crushed to remove the brain, but were also modified into vessels. At least one such skullcup was probably brought to the site from elsewhere. This kind of behaviour indicates that cannibalism was a ritual activity at this site, not a survival strategy. Skull-cups have also been found at the French sites of Le Placard (Fig. 3) and Isturitz, and in the El Castillo cave in Spain (Bello et al. 2015; Straus et al. 2011.1163). This could indicate that ritual cannibalism was part of funerary practices in the Magdale-

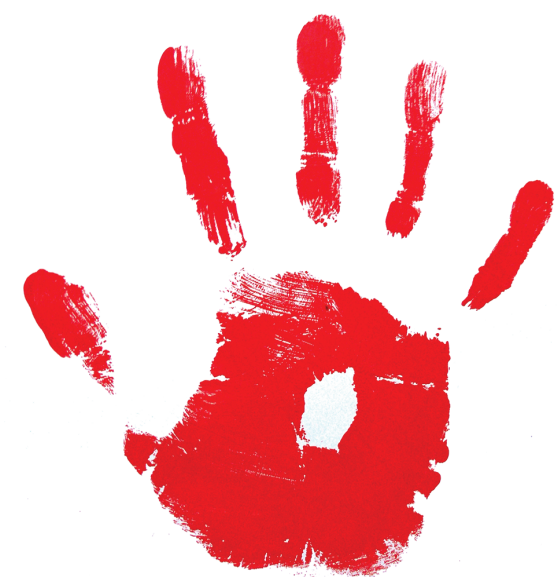

Fig. 2. A handprint as a lasting preservation of identity. nian (Bello et al. 2015). The focus on the head is also clear from the remains in the Maszycka cave in Poland. Several crushed skulls with traces of cannibalism were found there. These are probably the remains of two or three families that were killed, had their skulls crushed, and brain eaten. Other bones of their skeletons were found near the cave entrance, mixed with animal bones (Pettitt 2011.215-216, with references).

Secondary burials are also a reflection of the manipulation of human remains. In recent times, some Australian Aborigines have practiced such burials. They exposed the dead bodies for so long, that only the bones remained. Afterwards, the clean bones were ritually buried. Prior to burial, the remains were coloured with red ochre, since the red colour represents life (Jones 2000.261).

A Magdalenian secondary burial was found in the El Mirón cave in Spain, where the partial skeleton of a young adult was buried near a large block which had fallen from the cave roof. The wall near the human remains and the fallen block were engraved. Part of the block was stained with ochre, as were the skeletal remains and some of the stones covering the bones. A large quartz crystal was found in the context of the secondary burial, so it is possible that it was intentionally deposited with the bones. All of this indicates that the cleaned human remains were ritually buried (Straus et al. 2011). The presence of the quartz crystal as a possible grave offering could mean that the remains were of a person with special powers which were embodied in the crystal. Today's Central American Indian Huichol tribe believe that quartz crystals represent the souls of deceased shamans (Vitebsky 2001.23).

An unusual secondary burial from the same period is known from the Brillenhöhle site in Germany. The human remains include 38 fragments of a skull and skeleton on which traces of human manipulation can be seen. Parts of the skeleton were placed inside the skull-cup, which seems to be a transport-container. In this container, human remains might be stored in some other place or transported by the group for a longer period prior to the secondary burial. The burial is approximately contemporary with finds from Gough's Cave (Orschiedt 2002), and confirms the special, probably ritual, significance of Magdalenian skull-cups.

Multiple inhumations were more frequent in the Gravettian than later in the Palaeolithic, which could 


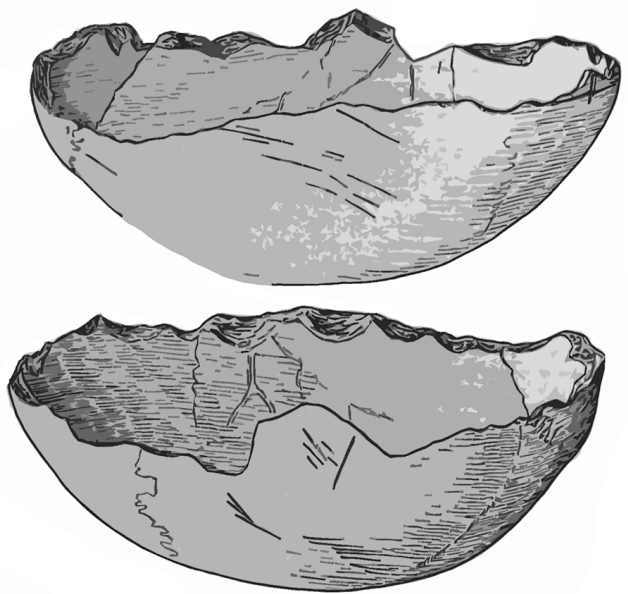

Fig. 3. Skull-cup from the Upper Palaeolithic at Le Placard in France (adapted from Macalister 1921. Fig. 113).

mean that views of personhood and social relations had changed with time (Riel-Salvatore, Gravel-Miguel 2013.326). At the end of the Palaeolithic, this perception probably changed even more. The first 'necropolis' at the Italian site of Arene Candide is preserved from this period. It includes at least 20 buried individuals of different genders and ages. They were placed in a layer imbued with ochre. Two of the burials are double. Some partial skeletons are damaged due to subsequent burials, and some of them seem to be secondary burials. Therefore, two types of handling of human remains were probably present in Arene Candide. Rich grave goods were added to those skeletons which were laid in the grave pit in an anatomical position, while secondary burials revealed no grave goods. Adults and children are found in the graves and representatives of both genders, but there are fewer women than men. The cave was used as a burial site in at least two periods; graves were possibly marked with stone blocks, and the cemetery area decorated with reindeer antlers. (Giacobini 2007.8; Pettitt 2011.251-253, with references). The ritual killing of pebble tools might also have been part of complex funeral ceremonies at this place (Riel-Salvatore et al. 2018).

A group burial from the Moravian site of Předmostí, in which a larger number of skeletal remains were preserved, is much older than the 'necropolis' at Arene Candide. In this case, people were buried along the impressive rock at the edge of the settlement. There are two interpretations of what was happening at the time of the inhumations. According to the first, it was a catastrophic event; according to the other, burials under the rock had been taking place for a long period, which could be interpreted as the first burial ground (Svoboda 2008). From the same site, the human manipulation of the remains of domesticated dog is known. A fragment of mammoth bone was between the jaws of one of the three specimens that were found at the site. The bone was placed there posthumously, which indicates that the act probably had a ritual meaning (Germonpré et al. 2012).

The increasingly important role of dogs at the end of the Palaeolithic is reflected in the burial of a dog from the Siberian site of Uški I. The dog was lying on its left side along the hearth inside a dwelling. Along its back was a blotch of ochre, in which a sidescraper, an obsidian blade and a grindstone were found (Dikov 2004.39). This burial indicates that dogs started to be perceived as persons, and were included in the human community. Humans are the only species capable of something like this. Such an expansion of identity probably happened in the Upper Palaeolithic, but dogs were even more present in people's lives later, in the Mesolithic. Other animals also became part of the community and were given an important place in social life and religion. Even today, the boundary between humans and animals is still very loose among some indigenous people, and animals can even assume the role of ancestral beings.

Identity in the Upper Palaeolithic spread from people not only to animals, but also to certain objects, which acquired special powers. An example of such 'strong' objects are female figurines which were buried inside dwellings at Russian sites (White 2003. $138-141$, with references), probably in order to protect them.

Many Upper Palaeolithic skeletons lacked jewellery or other grave goods (Riel-Salvatore, Gravel-Miguel 2013.333), which means that the dead were not all treated the same. At the time, numerous groups probably existed which did not believe in the afterlife, since even today some groups like the !Kung San from South Africa or East African Masai do not have a concept of life after death in their belief system (Dunbar 2004.194-195). Palaeolithic people who did not believe in the continuation of existence after death probably felt no need to enage in ritual burials; if they buried their dead, they did so for hygienic or safety reasons, since the bodies could attract predators.

\section{Conclusion}

It is possible that the practice of burials started differently than we generally imagine today. It might be that in the Upper Palaeolithic, it was not indivi- 
duals with high status that were buried, but rather people who were physically or mentally handicapped and were thus feared. It could be that they also buried those who broke social norms, and individu- als with special 'powers', whose corpses they did not want nearby due to fear. As suggested by Paul Pettitt (2011.212): "Perhaps human relics reflected 'good' deaths, and burials 'bad'."

\section{References}

Alt K. W., Pichler S., Vach W., Klíma B., Vlček E., and Sedlmeier J. 1997. Twenty-five thousand-year-old triple burial from Dolní Věstonice: an ice-age family? American Journal of Physical Anthropology 102(1): 123-131.

Bello S. M., Saladie P., Caceres I., Rodriguez-Hidalgo A., and Parfitt S. A. 2015. Upper Palaeolithic ritualistic cannibalism at Gough's Cave (Somerset, UK): The human remains from head to toe. Journal of Human Evolution 82: 170-189.

Dikov N. 2004. Early Cultures of Northeastern Asia. U.S. Department of the Interior, National Park Service, Shared Beringian Heritage Program. Anchorage.

Duarte C., Maurício J., Pettitt P., Souto P., Trinkaus E., van der Plicht H., and Zilhão J. 1999. The early Upper Paleolithic human skeleton from the Abrigo do Lagar Velho (Portugal) and modern human emergence in Iberia. Proceedings of the National Academy of Sciences of the USA 96: 7604-7609.

Dunbar R. 2004. The Human Story. A new history of mankind's evolution. Faber and Faber. London.

Formicola V. 2007. From the Sunghir Children to the Romito Dwarf. Current Anthropology 48(3): 446-453.

Formicola V., Pontrandolfi A., and Svoboda J. 2001. The Upper Paleolithic Triple Burial of Dolní Věstonice: Pathology and Funerary Behavior. American Journal of Physical Anthropology 115(4): 372-379.

Formicola V., Buzhilova A. 2004. Double Child Burial from Sunghir (Russia): Pathology and Inferences for Upper Paleolithic Funerary Practices. American Journal of Physical Anthropology 124(3): 189-198.

Formicola V., Holt B. 2015. Tall guys and fat ladies: Grimaldi's Upper Paleolithic burials and figurines in an historical perspective. Journal of Anthropological Sciences 93: 71-88.

Frayer D., Macchiarelli R., and Mussi M. 1988. A case of chondrodystrophic dwarfism in the Italian Late Upper Paleolithic. American Journal of Physical Anthropology 75: 549-565.
Germonpré M., Lázničková-Galetová M., and Sablin M. V. 2012. Palaeolithic dog skulls at the Gravettian Předmostí site, the Czech Republic. Journal of Archaeological Science 39(1): 184-202.

Giacobini G. 2007. Richness and Diversity of Burial Rituals in the Upper Paleolithic. Diogenes 54: 19-39.

Henry-Gambier D. 2001. La Sépulture des enfants de Grimaldi (Baoussé-Roussé, Italie). Anthropologie et palethnologie funéraire des populations de la fin du Paléolithique supérieur. Éditions du comité des Travaux historiques et scientifiques, Réunion des musées nationaux. Documents préhistoriques 14 . Paris.

Henry-Gambier D., Beauval C., Airvaux J., Aujoulat N., Baratin J.-F., and Buisson-Catil J. 2007. New hominid remains associated with gravettian parietal art (Les Garennes, Vilhonneur, France). Journal of Human Evolution 53(6): 747-750.

Jones R. 2000. Gun-gugaliya Rrawa: Place, ochre and death, a perspective from Aboriginal Australia. In S. Aldhouse-Green (ed.), Paviland Cave and the "Red Lady". A Definite Report. Western Academic and Specialist Press. Bristol: 247-264.

Klima B. 1988. A triple burial from the Upper Paleolithic of Dolní Věstonice, Czechoslovakia. Journal of Human Evolution 16(7-8): 831-835.

Macalister S. 1921. A Text-Book of European Archaeology, Vol. 1: the Palaeolithic period. Cambridge University Press. Cambridge.

Mittnik A., Wang C.-C., Svoboda J., and Krause J. 2016. A Molecular Approach to the Sexing of the Triple Burial at the Upper Paleolithic Site of Dolní Věstonice. PLOS ONE 11(10); on-line https://journals.plos.org/plosone/article?id $=10.13$ 71/journal.pone. 0163019

Mussi M. 2001. Earliest Italy: An Overview of the Italian Paleolithic and Mesolithic. Kluwer Academic/Plenum Publishers. New York, Boston, Dordrecht, London, Moscow.

Oliva M. 1999. The Brno II Upper Palaeolithic burial. Hunters of the golden age. Analecta praehistorica Leidensia 31: 143-153. 
Orschiedt J. 2002. Secondary burial in the Magdalenian: The Brillenhöhle (Blaubeuren, Southwest Germany). $P A$ LEO 14: 241-256.

Petru S. 2017. I remember. Differences between the Neanderthal and modern human mind. Documenta Praehistorica 44: 402-415. D0I: 10.4312/dp.44.25

Pettitt P. 2011. The Palaeolithic Origins of Human Burial. Routledge. London, New York.

Riel-Salvatore J., Gravel-Miguel C. 2013. Upper Palaeolithic Mortuary Practices in Eurasia: A Critical Look at the Burial Record. In L. Nilsson Stutz, S. Tarlow (eds.), The Oxford Handbook of the Archaeology of Death and Burial. Oxford University Press. Oxford: 303-346. http:// www.oxfordhandbooks.com/view/10.1093/oxfordhb/97 80199569069.001.0001/oxfordhb-9780199569069.

Riel-Salvatore J., Gravel-Miguel C., Maggi R., Martino G., Rossi S., and Sparacello V. S. 2018. New Insights into the Paleolithic Chronology and Funerary Ritual of Caverna delle Arene Candide. In V. Borgia, E. Cristiani (eds.), Palaeolithic Italy: Advanced studies on early human adaptations in the Apennine peninsula. Sidestone Press Academics. Leiden: 335-356.

Sinitsyn A. 2004. Les sepultures de Kostenki: chronologie, attribution culturelle, rite funéraire. La Spiritualité. Actes du colloque de la commission 8 de l'UISPP (Paléolithique supérieur), Liège, 10-12 décembre 2003. ERAUL 106: 237-244.

Straight B. 2013. Miracles and Extraordinary Experience in Northern Kenya. Contemporary Ethnography Series. University of Pennsylvania Press. Philadelphia.
Straus L. G., González Morales M. R., and Carretero J. M. 2011. Lower Magdalenian secondary human burial in El Mirón Cave, Cantabria, Spain. Antiquity 85(330): 11511164.

Svoboda J. 2008. The Upper Paleolithic burial area at Předmostí: ritual and taphonomy. Journal of Human Evolution 54(1): 15-33.

Tattersall I., Schwartz J. 1999. Hominids and hybrids: The place of Neanderthals in human evolution. Proceedings of the National Academy of Sciences of the United States of America 96: 7117-7119.

Trinkaus E., Buzhilova A., Mednikova M., and Dobrovolskaya M. 2014. The People of Sunghir: Burials, Bodies, and Behavior in the Earlier Upper Paleolithic. Human Evolution Series. Oxford University Press. NewYork.

Trinkaus E., Buzhilova A. 2018. Diversity and differential disposal of the dead at Sunghir. Antiquity 92(361): 7-21.

Vitebsky P. 2001. Shamanism. University of Oklahoma Press. Norman.

Verneau R. 1900. The Men of the Barma Grande (Baoussé-Roussé). Fr. Abbo Publisher. Baoussé-Roussé, near Mentone.

White R. 2003. Prehistoric art: the symbolic journey of humankind. Harry N. Abrams. New York.

\section{back to contents}

